\title{
Analysis of Morphological Characteristics and Variation in Five Populations of Zabelia tyaihyonii in South Korea
}

\author{
Jae $\mathrm{Ik} \mathrm{Nam}^{1}$, Mun Seop Kim² ${ }^{2}$, Jeong Ho Song ${ }^{2}$, Jeong Min Seo ${ }^{1}$, Go Eun $\mathrm{Choi}^{3}$, and Young Ki Kim${ }^{2 *}$ \\ ${ }^{1}$ Researcher, Division of Gardens Material Research, Sejong National Arboretum, Sejong 30106, Republic of Korea \\ ${ }^{2}$ Researcher, Special-purpose Trees Division, National Institute of Forest Science, Suwon 16631, Republic of Korea \\ ${ }^{3}$ Researcher, Research Planning and Coordination Team, Korea Arboreta and Gardens Institute, Sejong 30129, Republic of Korea
}

\section{ABSTRACT}

Background and objective: Native to the limestone zones of the Korean Peninsula, Zabelia tyaihyonii is a popular plant for landscaping. As it is now classified as a rare species, the conservation of its genetic resources is necessary.

Methods: In this study, which aimed to understand the morphological variation of $Z$. tyaihyonii, 18 characteristics of $Z$. tyaihyonii from five habitats were examined.

Results: Of these 18 characteristics, 16 characteristics showed significant differences among sites, and the coefficient of variation ranged from $5.4 \%$ (for corolla lobe number) to $31.3 \%$ (for flower number). Notable variations were observed in the size of flower and calyx lobe. When the corolla length and calyx lobe length were used as the classification key of $Z$. tyaihyonii, the sites were divided into those with small, intermediate, and large values. Hair was observed on the filament of all samples, a finding which conflicts with an earlier report. Rather than classifying $Z$. tyaihyonirinto different species on the basis of corolla length $(\mathrm{COL})$ and calyx lobe length $(\mathrm{CALL})$ values, we recommend modifying the species description to incorporate the variation in these characteristics of interest. Principal component analysis results showed that the first main component was highly correlated with the traits related to the size of the calyx lobe (length: 0.819, width: 0.758 ), and the second main component was highly correlated with the traits related with the size of the inflorescence (length: 0.790 , width: 0.626).

Conclusion: Several notable variations were identified among the characteristics related to inflorescence and calyx lobe. There is little genetic exchange among groups, or each group is influenced by micro environmental factors, because sites that are located nearby. In addition, the difference between COL and CALL, which is used as the classification key for $Z$. tyaihyonii, was divided into small group, large group, and intermediate group, regardless of the sites' geographical distance.

Keywords: endemic plant, intraspecific variation, Korean abelia, morphological variation, phenotypic plasticity

\section{Introduction}

The Convention on Biological Diversity, first signed in 1992, emphasizes restrictions on the exclusive rights to biological resources, as well as guiding profit sharing and the use of such resources. A systematic investigation of native plants in Korea will increase the possibility that potential genetic resources will be developed and will help prevent loss of these resources through poaching or overharvesting
(Jang, 2001). The Korean Peninsula is 64\% mountainous terrain, and includes many islands along the west and south coasts, which gives it richer biodiversity than other countries of similar size (Park, 2005). In particular, a great limestone series formed from deposited limestone and shale is concentrated in the southern area of Gangwon Province and the northern area of North Chungcheong Province (Kang, 1992). The soil in these areas contains a large amount of calcium and carbonate ions, which show weak

Received: November 11, 2021, Revised: November 25, 2021, Accepted: December 6, 2021

First author: Jae Ik Nam, silhouette@koagi.or.kr, (D) https://orcid.org/0000-0002-9800-563X

*Corresponding author: Young Ki Kim, treeace@korea.kr, (1D) https://orcid.org/0000-0002-1456-3256 
alkalinity and a tendency to dry easily (Larcher, 1975; Kim et al., 2005). Thus, it is slowly becoming covered in vegetation, forming a mat of native plants that shows a unique aspect of growth and evolution (Gauld and Robertson, 1985; Choo and Song, 1998; Ewald, 2003; Wohlgemuth and Gigon, 2003; Cottle, 2004; Yun and Moon, 2009).

Zabelia tyaihyonii (Nakai) Hisauti \& H. Hara is an indicator plant belonging to the family Caprifoliaceae that grows in the limestone zones, and is classified as a deciduous broadleaf shrub. It is native to the Korean Peninsula and is found only in parts of Danyang County in North Chungcheong Province and Yeongwol County in Gangwon Province (Lee, 2007; Korea National Arboretum, 2009). It has been traded under the names "Hardy abelia" and "Fragrant abelia" since its introduction to the United States in 1989, and is a preferred shrub for landscaping because of its light pink flowers in May and excellent cold tolerance (Sim and Seo, 1995). However, owing to habitat damage and illegal harvesting, it is now designated in the Korean Red List of Threatened Species as a rare plant that is endangered, so a systematic investigation for its conservation is urgently needed (Ann, 2012).

The scientific classification of $Z$. tyaihyonii is also controversial. Takenoshin Nakai reported on Z. tyaihyonii (collected in Maepo-eup, Danyang County, North Chungcheong Province) and Z. mosanensis (collected in Maengsan County, South Pyeongan Province). The two were considered distinct species because $Z$. tyaihyonii has smaller flowers and calyx lobe than Z. mosanensis, and does not have hair on the filament (Nakai, 1921, 1926). However, a reclassification may be necessary in order to divide or integrate the species, because the characteristics survey was limited to only a few regions (Hara, 1983; Paik and Lee, 1989). In addition, there is increasing confusion regarding the use of scientific names within this group of plants, including the genus Zabelia of the Caprifoliaceae family, the genus Abelia of the Caprifoliaceae family, and the genus Zabelia of the Linnaceae family, indicating that further studies are required for taxonomic review (Bart et al., 2010; Bell, 2010).

Native plants have the potential to develop into useful variants based on their environmental adaptability and high genetic diversity (Falk, 1991; Oostermeijer et al., 2003;
Barrett and Schluter, 2008). The value of native plants in biodiverse habitats and the use of their genetic resources are current areas of study; therefore, the search for and development of native plants has become an important project. It is essential to understand the characteristics and trait variations of target species for conservation and use. Therefore, the present study provides data on the morphological characteristics of the native $Z$. tyaihyonii and its variation among populations or individuals.

\section{Research Methods}

\section{Selection of habitats and sample trees}

To investigate the morphological characteristics and variation of Z. tyaihyonii, five habitats in Maepo-eup, Danyang County in North Chungcheong Province and Nam-myeon, Yeongwol County in Gangwon Province were selected, and 20 mature trees showing good growth were randomly selected from each habitat and used as test materials. Data on distribution were provided by the Ministry of Land Infrastructure and Transport in 2017 (Fig. 1, Table 1).

\section{Morphological characteristics study}

We investigated 18 characteristics related to inflorescence, flower, leaf, calyx lobe, and fruit in 100 samples. Inflorescence and flower characteristics were investigated during the flowering period in May, and leaf,

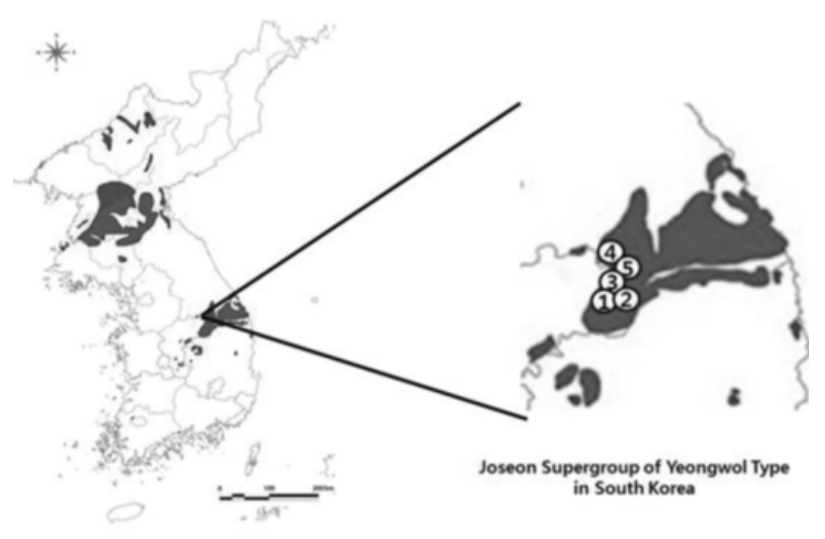

Fig. 1. Geographical distribution of Zabelia tyaihyonii population examined. 
Table 1. General description of selected Zabelia tyaihyonii populations

\begin{tabular}{|c|c|c|c|}
\hline Site & Locality & Latitude/longitude & Altitude (m) \\
\hline 1 & Yeongcheon-ri, Maepo-eup, Danyang County in North Chungcheong Province & $\begin{array}{c}37^{\circ} 4^{\prime} 2^{\prime \prime} \mathrm{N} \\
128^{\circ} 18^{\prime} 50^{\prime \prime} \mathrm{E}\end{array}$ & 202 \\
\hline 2 & Sangsi-ri, Maepo-eup, Danyang County in North Chungcheong Province & $\begin{array}{c}37^{\circ} 2^{\prime} 20^{\prime \prime} \mathrm{N} \\
128^{\circ} 18^{\prime} 27^{\prime \prime} \mathrm{E}\end{array}$ & 193 \\
\hline 3 & Hasi-ri, Maepo-eup, Danyang County in North Chungcheong Province & $\begin{array}{c}37^{\circ} 2{ }^{\prime} 27^{\prime \prime} \mathrm{N} \\
128^{\circ} 18^{\prime} 16^{\prime \prime} \mathrm{E}\end{array}$ & 164 \\
\hline 4 & Changwon-ri, Nam-myeon, Yeongwol County in Gangwon Province & $\begin{array}{c}37^{\circ} 9{ }^{\prime} 51^{\prime \prime} \mathrm{N} \\
128^{\circ} 21^{\prime} 14^{\prime \prime} \mathrm{E}\end{array}$ & 287 \\
\hline 5 & Togyo-ri, Nam-myeon, Yeongwol County in Gangwon Province & $\begin{array}{c}37^{\circ} 9^{\prime} 26^{\prime \prime} \mathrm{N} \\
128^{\circ} 20^{\prime} 20^{\prime \prime} \mathrm{E}\end{array}$ & 250 \\
\hline
\end{tabular}

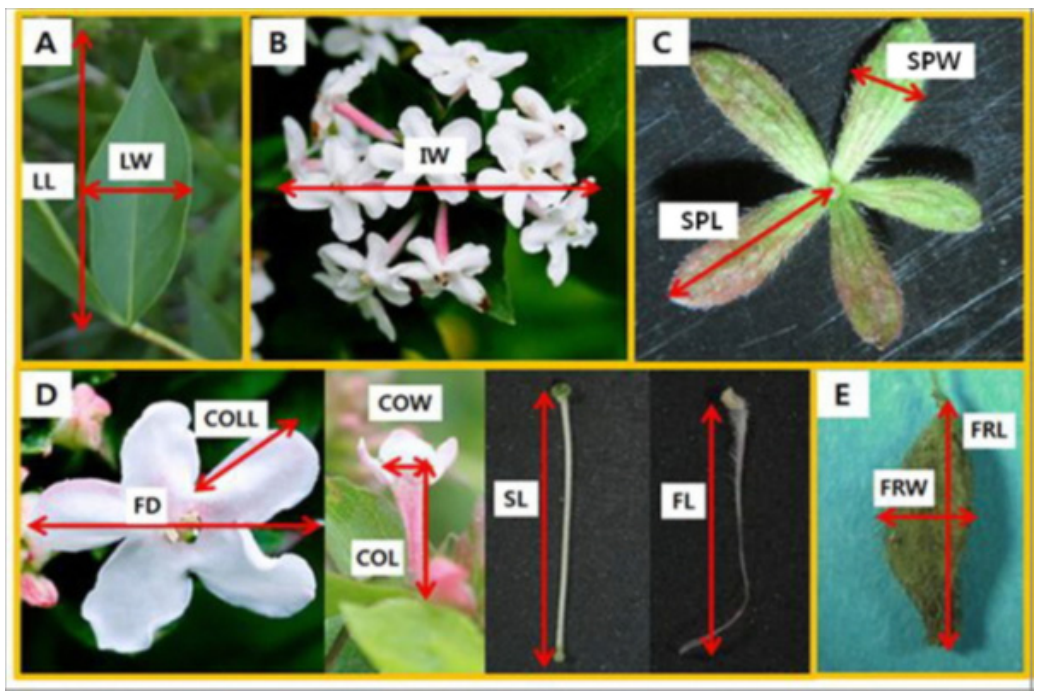

Fig. 2. Diagram of morphological characteristics of Zabelia tyaihyonii measured for morphological study.

Table 2. List of 18 morphological characteristics for phenetic analysis in Zabelia tyaihyonii

\begin{tabular}{|c|c|c|c|c|c|c|c|}
\hline Plant part & Characteristics & Abbreviation & Unit & Plant part & Characteristics & Abbreviation & Unit \\
\hline \multirow{3}{*}{ Leaf } & Leaf length & LL & $\mathrm{mm}$ & \multirow{7}{*}{ Flower } & Corolla length & $\mathrm{COL}$ & $\mathrm{mm}$ \\
\hline & Leaf width & LW & $\mathrm{mm}$ & & Corolla width & COW & $\mathrm{mm}$ \\
\hline & Petiole length & PL & $\mathrm{mm}$ & & Corolla lobe number & COLN & ea. \\
\hline \multirow{3}{*}{ Inflorescence } & Flower number & $\mathrm{FN}$ & ea. & & Corolla lobe length & COLL & $\mathrm{mm}$ \\
\hline & Inflorescence length & IL & $\mathrm{mm}$ & & Flower diameter & FD & $\mathrm{mm}$ \\
\hline & Inflorescence width & IW & $\mathrm{mm}$ & & Filament length & FL & $\mathrm{mm}$ \\
\hline \multirow{3}{*}{ Calyx } & Calyx lobe number & CALN & ea. & & Style length & SL & $\mathrm{mm}$ \\
\hline & Calyx lobe length & CALL & $\mathrm{mm}$ & \multirow{2}{*}{ Fruit } & Fruit length & FRL & $\mathrm{mm}$ \\
\hline & Calyx lobe width & CALW & $\mathrm{mm}$ & & Fruit width & FRW & $\mathrm{mm}$ \\
\hline
\end{tabular}

calyx lobe, and fruit-related characteristics were investigated at the end of October when growth ended. A characteristics investigation was conducted on branches located in 1/3 of crowns, and repeated 20 times for each sample (Fig. 2, Table 2). 
Table 3. Mean values of morphological characteristics of five populations in Zabelia tyaihyonii

\begin{tabular}{|c|c|c|c|c|c|c|c|c|c|c|c|c|c|c|c|c|c|c|c|}
\hline \multirow{2}{*}{\multicolumn{2}{|c|}{ Population }} & \multicolumn{18}{|c|}{ Characteristics $^{\mathrm{z}}$} \\
\hline & & $\mathrm{LL}$ & LW & PL & $\mathrm{FN}$ & IL & IW & $\begin{array}{l}\mathrm{CA} \\
\mathrm{LN}\end{array}$ & $\begin{array}{l}\mathrm{CA} \\
\mathrm{LL}\end{array}$ & $\begin{array}{l}\text { CA } \\
\text { LW }\end{array}$ & $\mathrm{COL}$ & COW & $\begin{array}{l}\mathrm{CO} \\
\mathrm{LN}\end{array}$ & $\begin{array}{l}\mathrm{CO} \\
\mathrm{LL}\end{array}$ & FD & FL & SL & FRL & FRW \\
\hline \multirow{2}{*}{ Site 1} & Mean & 50.5 & $20.7 \mathrm{by}$ & $3.7 \mathrm{~d}$ & $14.4 \mathrm{~b}$ & $29.0 \mathrm{~b}$ & $39.7 \mathrm{a}$ & $4.6 \mathrm{a}$ & $5.6 \mathrm{~d}$ & $1.4 \mathrm{~d}$ & $12.6 \mathrm{~d}$ & $3.2 \mathrm{~b}$ & 4.9 & $4.6 \mathrm{~b}$ & $12.1 \mathrm{~b}$ & $11.0 \mathrm{c}$ & $13.4 \mathrm{c}$ & $4.8 \mathrm{c}$ & $1.9 \mathrm{~b}$ \\
\hline & C.V. ${ }^{y}$ & 10.1 & 9.0 & 16.8 & 27.2 & 15.5 & 12.6 & 11.7 & 10.4 & 20.0 & 10.2 & 18.4 & 6.5 & 17.6 & 10.2 & 11.4 & 6.6 & 7.7 & 12.1 \\
\hline \multirow{2}{*}{ Site 2} & Mean & 50.0 & $19.4 \mathrm{~d}$ & $4.4 \mathrm{bc}$ & $8.1 \mathrm{~d}$ & $21.8 \mathrm{e}$ & $35.2 \mathrm{c}$ & $4.3 \mathrm{~b}$ & $6.4 \mathrm{c}$ & $1.8 \mathrm{~b}$ & $14.0 \mathrm{c}$ & $3.7 \mathrm{a}$ & 5 & $3.9 \mathrm{c}$ & $9.8 \mathrm{c}$ & $11.4 \mathrm{~b}$ & $12.9 \mathrm{~d}$ & $5.2 \mathrm{~b}$ & $1.8 \mathrm{c}$ \\
\hline & C.V. & 9.8 & 13.1 & 10.2 & 27.4 & 11.3 & 14.1 & 13.5 & 24.7 & 32.8 & 7.6 & 12.2 & 3.4 & 14.9 & 12.9 & 9.1 & 7.9 & 10.0 & 12.8 \\
\hline \multirow{2}{*}{ Site 3} & Mean & 49.2 & $20.2 \mathrm{c}$ & $4.5 \mathrm{a}$ & $12.5 \mathrm{c}$ & $29.7 \mathrm{a}$ & $40.1 \mathrm{a}$ & $4.4 \mathrm{~b}$ & $7.0 \mathrm{~b}$ & $1.7 \mathrm{c}$ & $16.4 \mathrm{a}$ & $3.8 \mathrm{a}$ & 5 & $4.7 \mathrm{~b}$ & $13.3 \mathrm{a}$ & $11.6 \mathrm{~b}$ & $15.6 \mathrm{a}$ & $4.9 \mathrm{c}$ & $2.0 \mathrm{~b}$ \\
\hline & C.V. & 10.9 & 13.7 & 14.2 & 25.4 & 11.5 & 11.1 & 12.5 & 9.9 & 17.1 & 9.9 & 17.6 & 3.4 & 17.9 & 13.8 & 17.2 & 7.2 & 7.3 & 10.5 \\
\hline \multirow{2}{*}{ Site 4} & Mean & 49.2 & $18.9 \mathrm{e}$ & $4.3 \mathrm{c}$ & $14.8 \mathrm{~b}$ & $24.1 \mathrm{~d}$ & $39.7 \mathrm{a}$ & $4.4 \mathrm{~b}$ & $5.5 \mathrm{~d}$ & $1.4 \mathrm{~d}$ & $12.2 \mathrm{e}$ & $2.9 \mathrm{c}$ & 4.9 & $4.7 \mathrm{~b}$ & $13.1 \mathrm{a}$ & $13.2 \mathrm{a}$ & $15.2 \mathrm{~b}$ & $4.6 \mathrm{~d}$ & $1.7 \mathrm{~d}$ \\
\hline & C.V. & 12.0 & 14.3 & 11.2 & 21.6 & 15.7 & 14.2 & 13.6 & 8.2 & 21.4 & 8.4 & 14.5 & 7.1 & 13.6 & 11.1 & 9.1 & 8.7 & 8.7 & 20.0 \\
\hline Site 5 & Mean & 49.2 & $21.8 \mathrm{a}$ & $4.4 \mathrm{~b}$ & $15.7 \mathrm{a}$ & $26.0 \mathrm{c}$ & $37.0 \mathrm{~b}$ & $4.2 \mathrm{c}$ & $8.7 \mathrm{a}$ & $2.5 \mathrm{a}$ & $15.7 \mathrm{~b}$ & $3.2 \mathrm{~b}$ & 4.9 & $5.8 \mathrm{a}$ & $11.8 \mathrm{~b}$ & $13.0 \mathrm{a}$ & $15.3 \mathrm{~b}$ & $5.4 \mathrm{a}$ & $2.2 \mathrm{a}$ \\
\hline \multirow{2}{*}{ Total } & Mean & 49.6 & 20.2 & 4.2 & 13.1 & 26.1 & 38.4 & 4.4 & 6.6 & 1.8 & 14.2 & 3.4 & 5 & 4.7 & 12.0 & 12.0 & 14.5 & 5.0 & 1.9 \\
\hline & C.V. & 10.3 & 12.7 & 14.3 & 31.3 & 18.0 & 14.6 & 12.7 & 22.7 & 30.0 & 15.4 & 19.4 & 5.4 & 21.1 & 15.8 & 13.7 & 11.0 & 9.8 & 16.8 \\
\hline
\end{tabular}

${ }^{\mathrm{z}}$ See Table 2 for these abbreviations.

${ }^{\mathrm{y}}$ Means within columns followed by different letters are significantly different according to Duncan's multiple range test at $p<.01$.

${ }^{\mathrm{x}}$ C.V.: coefficient of variation.

\section{Statistical analysis}

To identify differences between the sites, a variance analysis and Duncan's multiple tests were performed. A principal component analysis was performed to select traits that had a high contribution to the classification between sites, and to calculate the contribution of each principal component to the eigenvalues and overall variation. In addition, a non-weighted average combined cluster analysis was carried out using the principal component scores as a variance, and the analysis was carried out for five habitats to create a dendrogram depicting the calculated distances. Statistical analysis was carried out using SPSS ver. 17.0.

\section{Results and Discussion}

\section{Morphological characteristics of $Z$. tyaihyonii}

The morphological characteristics of $Z$. tyaihyonii collected from five habitats are shown in Table 3. There were significant differences among the sites in 16 characteristics, but not in leaf length $(\mathrm{LL}, p$-value $=0.055)$ or corolla lobe number $(\mathrm{COLN}, p$-value $=0.226)$. Among leaf-related traits, LL was not significantly different among sites, and leaf width (LW) and petiole length (PL) had variation co- efficients of $12.7 \%$ and $14.3 \%$, respectively, indicating only small variation between leaves.

Among the inflorescence-related traits, the flower number (FN) was 13.1 on average. The FN in Site 5 was 15.7, which was $19.9 \%$ higher than the average, while the $\mathrm{FN}$ in Site 2 was 8.1, which was 39.2\% lower than the average, showing large variation according to site. Inflorescence length (IL) and inflorescence width (IW) were $26.1 \mathrm{~mm}$ and $38.4 \mathrm{~mm}$ on average, respectively, and Site 3 showed the largest values (IL: $29.7 \mathrm{~mm}$, IW: $40.1 \mathrm{~mm}$ ), while the nearby Site 2 showed the smallest values (IL: $21.8 \mathrm{~mm}$, IW: $35.2 \mathrm{~mm}$ ).

The calyx lobe number (CALN) was 4 or 6 on most samples, with an average of 4.4. Site 1 had the largest number (4.6) and Site 5 had the smallest number (4.2). Because some of the samples only had two or three calyx lobes, this characteristic was considered to have large intra-individual variation. The calyx lobe length (CALL) and calyx lobe width (CALW) showed large variation among sites. CALL and CALW were $6.6 \mathrm{~mm}$ and $1.8 \mathrm{~mm}$ on average, with the largest sizes in Site 5 (CALL: $8.7 \mathrm{~mm}$, CALW: $2.5 \mathrm{~mm}$ ) and the smallest sizes in Site 4 (CALL: $5.5 \mathrm{~mm}$, CALW: $1.4 \mathrm{~mm}$ ) and Site 1 (CALL: $5.6 \mathrm{~mm}$, CALW: $1.4 \mathrm{~mm})$. Z. tyaihyonii had large variations in the shape and number of calyx lobes, and there were more 


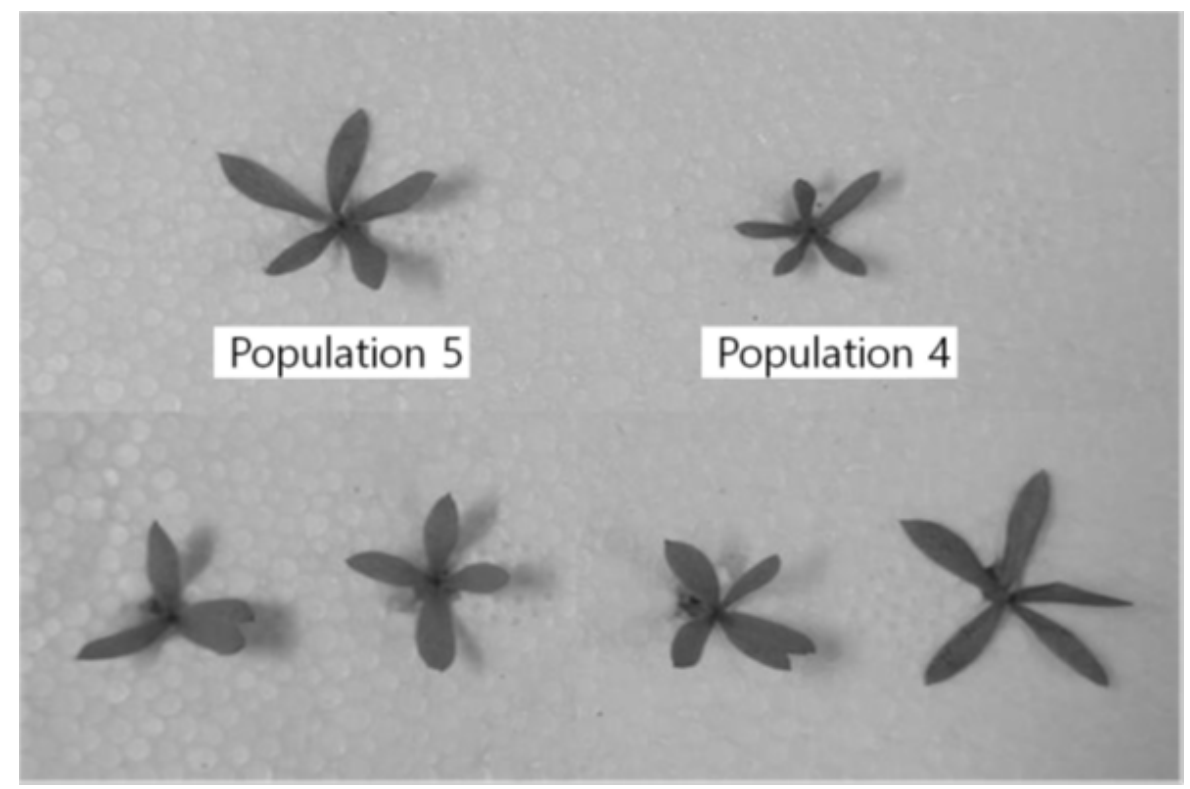

Fig. 3. Various shapes and number of calyx lobes found in Zabelia tyaihyonii.

complex variations, such as different calyx lobe sizes in the same flower or a split calyx lobe end. CALL and CALW obviously differed in size according to region, with values at the largest site (Site 5) $58.2 \%$ and $78.6 \%$ larger, respectively, than those at smaller sites (Site 1, Site 4) (Fig. 3).

The genus Zabelia demonstrates elongation of the calyx lobe after flowering, a characteristic that is known to be related to seed spreading by wind (Manchester and Donoghue, 1995). Plants with a drupe or berry can spread seeds by being eaten by animals, and plants with a capsule can make many seeds, which provide an advantage in spreading. However, as the fruit of the genus Zabelia cannot be eaten by animals it relies instead on the development of a unique structure, the elongated calyx lobe, for the timely spread of seeds. The size of the calyx lobe is closely related to seed spreading, and the distance of seed spreading increases as the calyx lobe develops (Strykstra et al., 1998). Further research is required on the phenomenon of seed spreading and genetic structure shown at Site 5, where CALL and CALW had higher values.

Among the characteristics related to flowers, the COLN was most commonly five petals, with no significant differences between the sites, although some corollas were split and contained fewer than four petals. The corolla width (COW), filament length (FL), and style length (SL) had coefficient of variation values of $19.4 \%, 13.7 \%$, and $11.0 \%$, respectively, showing only small variation. The corolla length (COL) and flower diameter (FD), which were directly related to the size of the flower, were the largest at Site 3 (COL: $16.4 \mathrm{~mm}$, FD: $13.3 \mathrm{~mm}$ ), more than $30 \%$ larger than at other sites.

There were variations among the sites in most characteristics studied; characteristics related to the size of inflorescence or calyx lobe showed more significant variations. Among these, COL and CALL, as well as the existence of filament hair, are characteristics that may be used to differentiate $Z$. tyaihyonii (COL: about $10 \mathrm{~mm}$, CALL: 4-6 mm, without filament hair) and $Z$. mosanensis (COL: about $15 \mathrm{~mm}$, CALL: 7-10 mm, with filament hair) (Nakai, 1921, 1926; Chung and Sun, 1984). According to the existing classification system, Site 3 (COL: $16.4 \mathrm{~mm}$, CALL: $7.0 \mathrm{~mm}$ ) and Site 5 (COL: $15.7 \mathrm{~mm}$, CALL: 8.7 $\mathrm{mm}$ ) plants belong to Z. mosanensis, and Site 1 (COL: $12.6 \mathrm{~mm}$, CALL: $5.6 \mathrm{~mm}$ ) and Site 4 (COL: $12.2 \mathrm{~mm}$, CALL: $5.5 \mathrm{~mm}$ ) plants belong to Z. tyaihyonii. However, at Site 2 (COL: $14.0 \mathrm{~mm}$, CALL: $6.4 \mathrm{~mm}$ ), COL and CALL had intermediate values, and dense filament hair was present in all samples from the five sites (Fig. 4). Therefore, we believe that the absence of hair in the filament of $Z$. tyaihyonii reported by Nakai (1921) was an error. More 


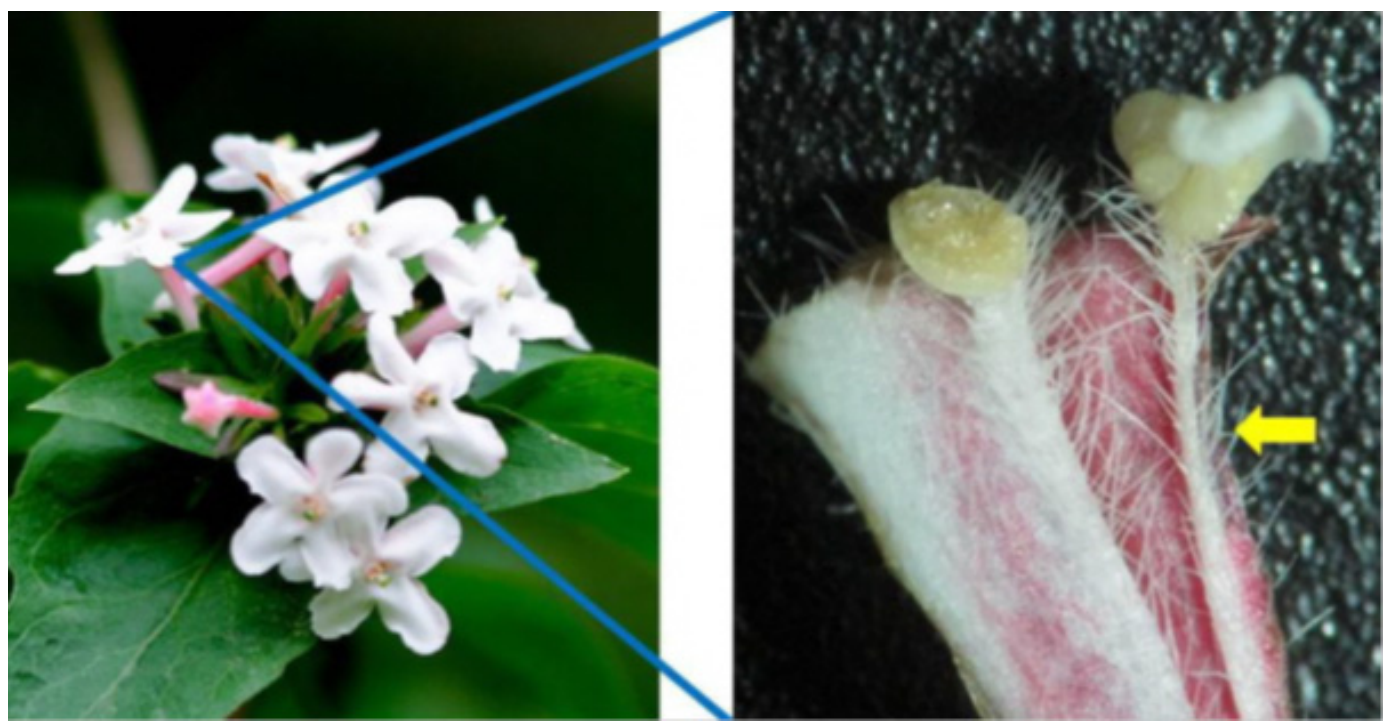

Fig. 4. Stamen filaments are covered with hairs.

careful study is needed in order to distinguish the two species, such as verification of morphological characteristics by planting the samples collected from different groups in the same environment.

The classification of Z. tyaihyonii and Z. mosanensis is a topic of debate. The Ministry of Environment labeled the two species separately, and the Korea Forest Service considers only $Z$. tyaihyonii to be a Korean native plant, so it is important to understand the true scientific status in order to properly manage these resources (Choi, 2015). Since the publication of the research of Nakai (1921, 1926), various opinions have been presented. Hara (1983) reported on only a few observable samples, which made it difficult to distinguish the taxonomic group. Sun (1999) suggested combining the two species, because the reference specimens of $Z$. tyaihyonii were collected during the fruiting season, making it difficult to compare flowers, and filament hairs were observed in all samples collected in the same region as the reference specimens. However, because molecular phylogeny studies using chloroplast DNA showed that $Z$. tyaihyonii and $Z$. mosanensis had distinct differences in the sequences of $r b c \mathrm{~L}$ and $m a t \mathrm{~K}$, there is evidence that they are independent species or intraspecies variants (Lee et al., 2009).

$Z$. tyaihyonii is a calciphyte that only grows in the limestone zone of the Joseon Supergroup, a limited range. The limestone zone has a single-grained structure, and the soil dries easily because of the good drainage. Water is an important environmental factor that affects the growth and distribution of terrestrial plants, and it is known that a lack of moisture inhibits the expansion of the cells involved in the growth of buds and stems, causing them to be smaller in size (Borchert, 1994). Unlike widely distributed species, native plants distributed in a narrow range are differentiated into resistant species through their evolution of smaller organs or increased energy metabolism to adapt to stressful habitats (Lavergne et al., 2004). In a study of plants from the genus Aquilegia growing in adjacent areas, A. vulgaris and A. pyrenaica subsp. cazorlensis, Medrano et al. (2006) showed that the latter species had much more distinct ecological differentiation between groups and was distributed in small areas compared with the widely distributed $A$. vulgaris. In addition, A. pyrenaica subsp. cazorlensis grows in the shallow sand of the limestone zone and is greatly affected by environmental stress. As Z. tyaihyonii also grows in a confined limestone zone, the environmental stress of this habitat may influence its ecological differentiation.

Tewari et al. (2016) analyzed the correlation between environmental factors and bud size of Rhododendron arboreum, a species that is native to the Himalayan region. They concluded that temperature has no significant influ- 
ence, while soil humidity $(r=0.69)$ and moisture potential of branches $(r=0.43)$ were highly correlated with bud size. It appears that in the temperate and Atlantic climates of Europe and North America, where soil water is typically present, temperature is a major factor in growth. However, in areas that are more prone to dryness, the moisture level at the early stage of organ development affects the size of flower buds (Parmensan and Yohen, 2003; Richardson et al., 2006; Way, 2011). Galen (1999) also found that the larger the corolla volume, the greater the water stress that the plant experienced, and Polemonium viscosum, which grows in dry areas, shows an increased water demand as the corolla grows; the corolla size varied according to the soil moisture level, even between adjacent samples.

As the five survey sites in the present study are located within a $10 \mathrm{~km}$ area and there is no significant difference in altitude among them, the differences in meteorological factors are expected to be small. Therefore, variation in morphological characteristics in Z. tyaihyonii, which is dis- tributed locally in the well-drained limestone zone, are thought to be closely associated with soil humidity. For this reason, it is inappropriate to distinguish $Z$. tyaihyonii, the indicator plant of the limestone zone, from Z. mosanensis by using COL and CALL measurements for $Z$. tyaihyonii. To distinguish these species, data regarding the variation in flower and calyx lobe size are required.

\section{Principal component analysis}

A principal component analysis was conducted on 18 morphological characteristics related to leaf, inflorescence, flower, and fruit from 100 specimens sampled from the five sites in Korea. Table 4 shows the correlation coefficient analyzed from eigenvalues of each principal component and the morphological characteristics. The eigenvalue of the first principal component was 3.15 , which explained $17.5 \%$ of the total variance, and those of CALL, CALW, and fruit width (FRW) were $0.819,0.758$, and

Table 4. Eigenvector association to eigenvalue obtained from principal component

\begin{tabular}{|c|c|c|c|c|c|}
\hline Characteristics $^{\mathrm{z}}$ & Principle 1 & Principle 2 & Principle 3 & Principle 4 & Principle 5 \\
\hline LL & -.030 & -.001 & .063 & -.075 & .795 \\
\hline LW & .401 & .114 & .137 & -.003 & .586 \\
\hline PL & .085 & -.045 & -.120 & .762 & .115 \\
\hline $\mathrm{FN}$ & .140 & .248 & .708 & -.101 & -.017 \\
\hline IL & .163 & .790 & -.015 & -.090 & .025 \\
\hline IW & -.102 & .626 & .017 & .059 & .074 \\
\hline CALN & -.175 & .288 & -.079 & -.210 & .043 \\
\hline CALL & .819 & -.103 & .038 & .254 & .054 \\
\hline CALW & .758 & -.225 & .073 & .190 & .093 \\
\hline $\mathrm{COL}$ & .592 & .230 & -.270 & .368 & -.085 \\
\hline COW & .189 & .088 & -.632 & .138 & -.060 \\
\hline COLN & -.086 & .030 & -.153 & .199 & .310 \\
\hline COLL & .490 & .171 & .419 & .041 & .017 \\
\hline FD & -.107 & .548 & .402 & .253 & -.090 \\
\hline FL & .084 & -.224 & .552 & .371 & .002 \\
\hline SL & .176 & .317 & .386 & .530 & -.259 \\
\hline FRL & .563 & -.290 & -.177 & -.104 & .177 \\
\hline FRW & .622 & .127 & .068 & -.237 & -.206 \\
\hline Eigenvalue & 3.147 & 2.275 & 1.480 & 1.340 & 1.163 \\
\hline Proportion & 0.175 & 0.126 & 0.082 & 0.075 & 0.065 \\
\hline Cumulative (\%) & 17.5 & 30.1 & 38.3 & 45.8 & 52.3 \\
\hline
\end{tabular}

${ }^{\mathrm{z}}$ Abbreviations of characteristics are the same as those of Table 2 . 


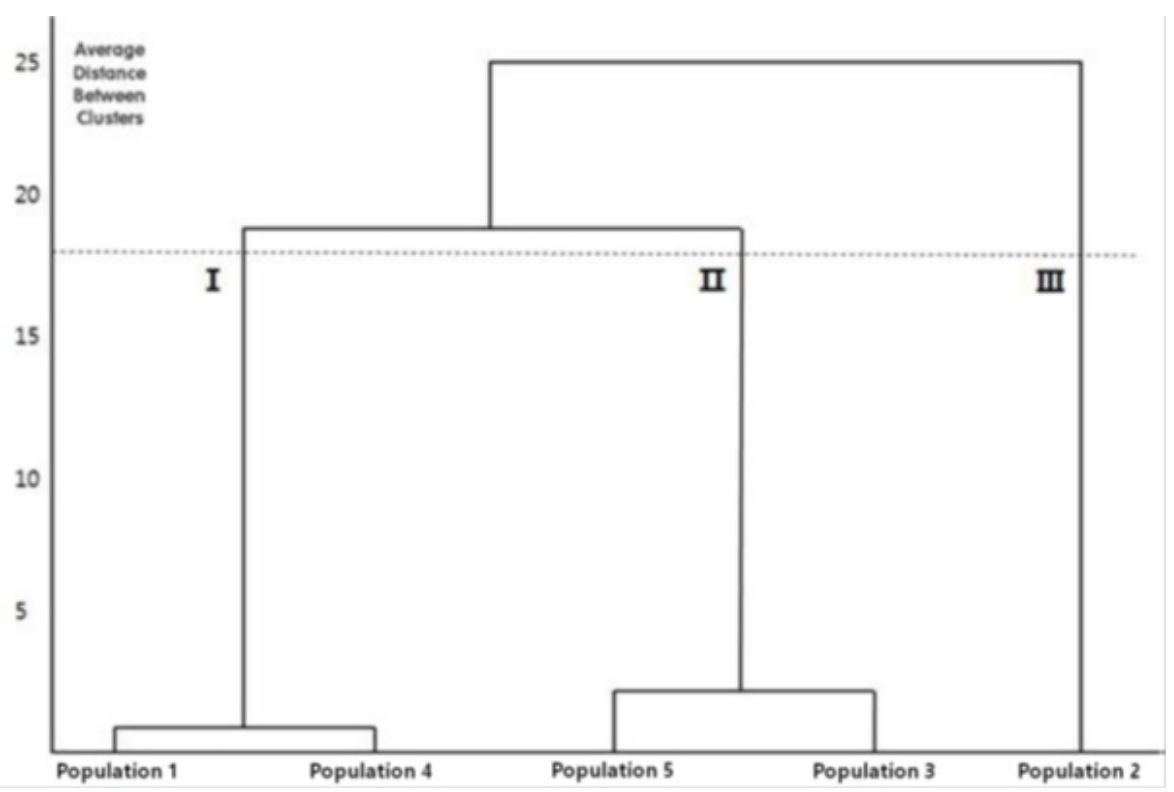

Fig. 5. Dendrogram of five populations in Zabelia tyaihyonii based on analyzed morphological characteristics.

0622, respectively, indicating a high correlation with traits related to calyx lobe size. The eigenvalue of the second principal component was 2.28 , which explained $12.6 \%$ of the total variance, and IL and IW values were 0.790 and 0.626 , indicating a high correlation with traits related to the inflorescence size. For the third principal component, the eigenvalue was 1.48 , accounting for $8.2 \%$ of the total variance, and FN (0.708) showed the highest correlation (Table 4). These results suggested that the size of the calyx lobe and inflorescence, which differed significantly between sites, made significant contributions to determining the morphological characteristics of Z. tyaihyonii and could be used to reveal the relationship between the groups. However, the cumulative explanatory power using five main components with eigenvalues of 1.0 or more was $52.3 \%$, which was significantly lower than that of the main component analysis of other species (Korean stewartia: 91.3\%, silver magnolia: $92.8 \%$, Japanese angelica: $76 \%$ ), indicating that the interpretation of data using only reduced principal components is inappropriate (Kim et al., 2005; Yang et al., 2011; Kim et al., 2013).

\section{Cluster analysis}

The cluster analysis classified the samples into three clusters. Site 2, from which the samples had small in- florescences and fewer flowers, was divided into an independent cluster first. Next, Site 1 and Site 4, from which the samples had smaller COL and CALL values, were clustered together, and Site 3 and Site 5, from which the samples had larger COL and CALL values, were clustered together (Fig. 5). The five sites are considered to form clusters due to their different growth environments, regardless of their geographical distance. Sites with similar values of COL and CALL used as the classification keys form clusters together.

\section{Conclusion}

Most of the morphological characteristics differed among the sites, and several notable variations were identified among the characteristics related to inflorescence and calyx lobe. There is likely little genetic exchange among groups, or each group is influenced by micro environment factors such as soil moisture, because sites that are located nearby. In addition, the difference between $\mathrm{COL}$ and CALL, which is used as the classification key for Z. tyaihyonii, was divided into small group (Site 1, Site 4), large group (Site 3, Site 5), and intermediate group (Site 2), regardless of the sites' geographical distance. In future, an environmental investigation of the $Z$. tyaihyonii habitats 
should be undertaken and DNA mutation analysis should be performed on the collected samples to assist in the conservation of $Z$. tyaihyonii. The results of that analysis will clarify whether $Z$. tyaihyonii and $Z$. mosanensis should be combined or retained as separate species.

\section{References}

Ann, Y.S. 2012. Red data book of endangered vascular plants in Korea (p. 128). Incheon, Korea: National institute of biological resources press (in Korean).

Barrett, R.D.H. and D. Schluter. 2008. Adaptation from standing genetic variation. Trends Ecol. Evol. 23(1): 38-44. https://doi.org/10.1016/j.tree.2007.09.008

Bart, J., P. Nancy, and S. Erik. 2010. Phylogeny of the linnaea clade: Are Abelia and Zabelia closely related?. Mol. Phylogenet. Evol. 57(2):741-752. https://doi.org/ 10.1016/j.ympev.2010.08.007

Bell, C.D. 2010. Towards a species level phylogeny of Symphoricarpos (Caprifoliaceae) based on nuclear and chloroplast DNA. Syst. Bot. 35:442-450. https://doi.org/10.1600/036364410791638351

Borchert, R. 1994. Soil and stem water storage determine phenology and distribution of tropical dry forest trees. Ecology 75(5):1437-1449. https://doi.org/10.2307/1937467

Choi, B.H. 2015. A study on the taxonomic enumeration of Korean endemic vascular plants (p. 91). Korea Forest Service, Research report, Daejeon, Korea (in Korean).

Choo, Y.S. and S.D. Song. 1998. Ecophysiological characteristics of plant taxon-specific calcium metabolism. Korean J. Ecol. 21(1):47-63

Chung, Y.H. and B.Y. Sun. 1984. Monographic study on the endemic plants of Korea IV: Taxonomy and interspecific relationships of the genus Abelia. Korean J. Plant Taxon. 14(3):137-152. https://doi.org/10.11110/kjpt. 1984.14.3.137

Cottle, R. 2004. Linking geology and biodiversity. Engl. Nat. Res Rep. 562:10-37.

Ewald, J. 2003. The calcareous riddle: Why are there so many calciphilous species in the central European flora?. Folia Geobot. 38(4):357-366.

Falk, D.A. 1991. Joining biological and economic models for conserving plant genetic diversity. In D. A. Falk and K.E. Holsinger (Eds.), Genetics and conservation of rare plants (pp. 209-223). Oxford, UK: Oxford University Press.

Galen, C. 1999. Why do flowers vary? The functional ecology of variation in flower size and form within natural plant populations. BioScience 49(8):631-640. https:// doi.org/10.2307/1313439

Gauld, J.H. and J.S. Robertson. 1985. Soils and their related plant communities of the Dalradian limestone of some sites in central Perthshire, Scotland. J. Ecol. 73(1):91-112. https://doi.org/10.2307/2259771

Hara, H. 1983. A revision of Caprifoliaceae of Japan with reference to allied plants in other districts and the Adoxaceae. Ginkgoana 5:136-173.

Jang, H.M. 2001. A study on national framework for conservation and management of Korean plant variety (pp. 58-94). Korea Research Institute of Bioscience and Biotechnology, Research report, Daejeon, Korea. http:// dl.nanet.go.kr/law/SearchDetailView.do?cn=MONO120 0209550\#none

Kang, Y.P. 1992. Study of the pedogenesis of red soils and karst geomorphology in the paleozoic limestone area in Korea: Examples of the region of Youngweol, Pyeong-chang and Samcheog. J. Korean Earth Sci. Soc. 13(2):156-175.

Kim, J.S., B.C. Lee, J.M. Jung, and J.H. Park .2005. Flora and phytogeography on Mt. Deokhang (Gangwon-do), limestone area in Korea. Korean J. Plant Taxon. 35(4):337-364.

Kim, Y.J., K.C. Kim, B.S. Lee, G.Y. Lee, K.J. Cho, J.T. Kang, and T.D. Kim. 2005. The variation of leaf characteristics in 6 natural populations of Stewartia koreana Nakai. J. Korean Soc. For. Sci. 94(6):446-452.

Kim, S.H., M.S. Kim, J.G. Han, H.S. Kim, and H.K. Moon. 2013. Morphological characteristics and classification of 25 selected clones of Aralia elata Seem. Korean J. Plant Resour. 26(1):36-43. https://doi.org/10.7732/kjpr.2013. 26.1.036

Korea National Arboretum. 2009. Rare plants data book of Korea (p. 148). Pocheon, Korea: GeoBook Publishing Co.

Larcher, W. 1975. Physiological plant ecology (p. 252). Berlin, Germany: Springer-Verlag.

Lavergne, S, J.D. Thompson, E. Garnier, and M. Debussche. 
2004. The biology and ecology of narrow and widespread plants: a comparative study of trait variation in 20 congeneric pairs. Oikos. 107(3):505-518. https://doi.org/10.1111/j.0030-1299.2004.13423.x

Lee, Y.N. 2007. In new flora of Korea (p. 236). Seoul, Korea: Kyohak Publishing Co.

Lee, B.Y., S.J. Kim, and Y.C. Kim. 2009. Molecular phylogeny of the genus Zabelia in Korea (p. 30). Incheon, Korea: National Institute of Biological Resources Press.

Manchester, S.R. and M.J. Donoghue. 1995. Winged fruits of Linnaeeae (Caprifoliaceae) in the tertiary of western North America: Diplodipelta gen. nov. Int. J. Plant Sci. 156(5):709-722.

Medrano, M., M.C. Castellanos, and C.M. Herrera. 2006. Comparative floral and vegetative differentiation between two European Aquilegia taxa along a narrow contact zone. Plant Syst. Evol. 262:209-224. https://doi.org/10.1007/s00606-006-0473-2

Ministry of Land Infrastructure and Transport (MOLIT). 2017. The national atlas of Korea comprehensive edition (pp. 72-73). National Geographic Information Institute, Suwon, Korea.

Nakai, T. 1921. Tentamen systematis Caprifoliacearum japonicarum. Coll. Sci. Imp. Univ. Tokyo 43:107-119.

Nakai, T. 1926. Notulae ad plantas Japoniae et Korea. Bot. Mag. Tokyo 40:463-495.

Oostermeijer, J.G.B., S.H. Luijten, and J.C.M. den Nijs. 2003. Integrating demographic and genetic approaches in plant conservation. Biol. Conserv. 113:389-398. https://doi.org/10.1016/S0006-3207(03)00127-7

Paik, W.K. and W.T. Lee. 1989. A taxonomic study of the genus Abelia in Korea. Korean J. Plant Taxon. 19:139-156. https://doi.org/10.11110/kjpt.1989.19.3.139

Park, C.W. 2005. Recent progress in floristic research in Korea. In K. Esser, U. Lüttge, W. Beyschlag, and J. Murata (Eds.), Progress in botany. Genetics physiology systematics ecology (pp. 345-360). Berlin, Germany: Springer Press. DOI:10.1007/3-540-27998-9_15

Park, Y.H. 2007. Analysis of a cross-cutting issue, 'Access to genetic resources and benefit sharing' of the conference of the parties to the convention on biological diversity. J. Environ. Pol. 6(1):41-60.

Parmensan, C. and G. Yohe. 2003. A globally coherent fingerprint of climate change impacts across natural ecosystems. Nature 421:37-42.

Richardson, A.D., A.S. Bailey, E.G. Denny, C.W. Martin, and J. O'Keefe. 2006. Phenology of a northern hardwood canopy. Glob. Change Biol. 12:1174-1188. https:// doi.org/10.1111/j.1365-2486.2006.01164.x

Sim, K.K. and B.K. Seo. 1995. Korean native shrubs and vines in North America landscape. J. Korean Flower Res. Soc. 4(2):37-62.

Strykstra, R.J., D.M. Pegtel, and A. Bergsma. 1998. Dispersal distance and achene quality of the rare anemochorous species Arnica montana L.: Implications for conservation. Acta Bot. Neerl. 47(1):45-56.

Sun, B.Y. 1999. Taxonomy and phylogenetic relationship of the genus Abelia (Caprifoliaceae) (p. 57). Research report, Daejeon, Korea: Korea Science and Engineering Foundation.

Tewari, A., J. Bhatt, and A. Mittal. 2016. Influence of tree water potential in inducing flowering in Rhododendron arboreum in the central Himalayan region. IForest 9(5):842-846. https://doi.org/10.3832/ifor1525-008

Way, D.A. 2011. Tree phenology responses to warming: spring forward, fall back?. Tree Physiol. 31(5):469-471. https://doi.org/10.1093/treephys/tpr044

Wohlgemuth, T. and A. Gigon. 2003. Calcicole plants diversity in Switzerland may reflect a variety of habitat templets. Folia Geobot. 38(4):443-452. https://doi.org/ 10.1007/BF02803251

Yang, B.H., J.H. Song, J.C. Lee, and Y.G. Park. 2011. The leaf morphological variation of ten regions of natural populations of Machilus thunbergii in Korea. J. Agric. Life Sci. 45(3):25-33.

Yun, C.W. and H.S. Moon. 2009. Classification of forest vegetation type and environmental properties in limestone area of Korea. J. Agric. Life Sci. 43(2):1-8. 